\title{
Chromatin remodeling by the CHD7 protein is impaired by mutations that cause human developmental disorders
}

\author{
Karim Bouazoune*, Robert E Kingston \\ From Epigenetics \& Chromatin: Interactions and processes \\ Boston, MA, USA. 11-13 March 2013
}

\section{Background}

Mutations in the CHD7 gene cause CHARGE, a developmental syndrome which affect most organs. In addition, CHD7 mutations also cause puberty and reproductive organ formation disorders such as Idiopathic Hypogonadotropic Hypogonadism and Kallmann Syndrome. Genetic studies in model organisms have further established $\mathrm{CHD} 7$ as a central regulator of vertebrate development. To understand how the CHD7 proteins achieve its function and how mutation of CHD7 leads to developmental disorders, it is critical to characterize WT and mutant CHD7 proteins biochemically. However to date, CHD7 has not been characterized for activity, as it is extremely large and has resisted purification.

\section{Materials and methods}

We used the baculovirus system and a dual-tag strategy to purify intact recombinant WT and mutant CHD7 proteins. We subjected these polypeptides to nucleosome remodeling and ATPase assays to characterize the CHD7 basic properties, perform a structure-function analysis of CHD7 and examine point mutants reported in human patients.

\section{Results}

We show that CHD7 is an ATP-dependent nucleosome remodeling factor and that it has characteristics distinct from SWI/ SNF- and ISWI-type remodelers. Further investigations show that $\mathrm{CHD} 7$ patient mutations have consequences that range from subtle to complete inactivation of remodeling activity, raising the possibility that even partial impairment of remodeling function has a significant impact

Department of Molecular Biology, Massachusetts General Hospital \& Department of Genetics, Harvard Medical School, Boston, MA, USA on human biology. In addition, we find that patient mutations leading to protein truncations upstream of amino acid 1899 of CHD7 are likely to cause a hypomorphic phenotype for remodeling.

\section{Conclusions}

We propose that nucleosome remodeling is a key function for CHD7 during developmental processes and provide a molecular basis for predicting the impact of disease mutations on that function.

Published: 8 April 2013

doi:10.1186/1756-8935-6-S1-P107

Cite this article as: Bouazoune and Kingston: Chromatin remodeling by the CHD7 protein is impaired by mutations that cause human developmental disorders. Epigentics \& Chromatin 2013 6(Suppl 1):P107.

Submit your next manuscript to BioMed Central and take full advantage of:

- Convenient online submission

- Thorough peer review

- No space constraints or color figure charges

- Immediate publication on acceptance

- Inclusion in PubMed, CAS, Scopus and Google Scholar

- Research which is freely available for redistribution
C Biomed Central

() 2013 Bouazoune and Kingston; licensee BioMed Central Ltd. This is an Open Access article distributed under the terms of the Creative Commons Attribution License (http://creativecommons.org/licenses/by/2.0), which permits unrestricted use, distribution, and reproduction in any medium, provided the original work is properly cited. 